\title{
Influence of Customized Fertilizer and Different Methods of Sowing on Wheat (Triticum aestivum L.)
}

\author{
Chereddy Maheshwara", Chakravarthy Thejesh and Joy Dawson \\ Department of Agronomy, Sam Higginbottom University of Agriculture, Technology and \\ Sciences, Prayagraj, Uttar Pradesh, India \\ *Corresponding author
}

\section{A B S T R A C T}

\section{Keywords}

Wheat yield, line sowing, SWI, Customized fertilizer, RDF

\section{Article Info}

Accepted:

25 September 2020 Available Online: 10 October 2020
The experiment was conducted during the rabi season 2019-2020, at the Crop Research Farm, Department of Agronomy, Naini Agricultural Institute, Sam Higginbottom University of Agriculture, Technology and Sciences (SHUATS), Prayagraj (U.P.) to evaluate the "Influence of Customized Fertilizer and Different Methods of Sowing on Wheat (Triticum aestivum L.)". The experiment was laid out in a Randomized block design with three replications. The treatments comprised of $\mathrm{T}_{1}-$ Line sowing $+\mathrm{SRDF}$ $(100 \%), \mathrm{T}_{2}-$ Broad casting +SRDF $(100 \%), \mathrm{T}_{3}-\mathrm{SWI}+\mathrm{SRDF}(100 \%), \mathrm{T}_{4}-$ Line sowing $+100 \%$ RDF through $\mathrm{CF}, \mathrm{T}_{5}-$ Broad casting $+100 \%$ RDF through $\mathrm{CF}, \mathrm{T}_{6}-\mathrm{SWI}+100 \%$ RDF through $\mathrm{CF}, \mathrm{T}_{7}-$ Line sowing $+75 \% \mathrm{RDF}$ through $\mathrm{CF}, \mathrm{T}_{8}-$ Broad casting+75\% RDF through $\mathrm{CF}, \mathrm{T}_{9}-\mathrm{SWI}+75 \% \mathrm{RDF}$ through $\mathrm{CF}$. The plant height was maximum in SWI + $100 \%$ RDF through CF (89.45), Number of tillers were higher in SWI $+100 \%$ RDF through CF (12.2), the maximum dry weight was noted in SWI $+100 \%$ RDF through CF (26.99).The grain yield, straw yield and harvest index is highest in the Line sowing + $100 \%$ RDF through CF 4.52, 3.5 and $44.85 \%$, respectively. The highest net return and $\mathrm{B}: \mathrm{C}$ ratio is observed in the treatment line sowing + 100\% RDF through $\mathrm{CF}$, Rs. 53809.89 and 1.8 respectively.

\section{Introduction}

Wheat (Triticum aestivum L.) is one of the most important cereal crops with a unique protein (gluten), which is consumed by humans and is cultivated around the world in varied environments. Globally wheat is cultivated in an area of about 220 million hectares with a record production of 763.06 million tonnes of grain. The maximum area under wheat cultivation is in India (14\%), followed by Russia (12.43\%), China
$(11.14 \%)$, and the USA $(6.90 \%)$ which in total accounts for about $45 \%$ of the global area. In India, wheat cultivated area rose to 30.54 million hectares from 29.04 million hectares with a net gain of $5 \%$ in terms area APEDA (2019).

In India, wheat is sown through the broadcasting method to a large extent followed by rice harvesting. The broadcasting method not only demands a high seed rate but also marks in a lesser plant population and 
yield (Singh et al., 2005). The foremost agronomic factors seed rate and method of sowing govern the crop vigour and eventually the yield. The selection of appropriate sowing method plays a significant role in the placement of seed at the required depth, which ensures better emergence, and consequent crop growth. Inappropriate planting methods, seed rate, and crop management practices will incur lower wheat yield. Whereas, the drill sowing ensures the uniform seed distribution and sowing at the desired depth, results in a higher germination rate and uniform establishment of the crop. System of Wheat Intensification (SWI) is another method of sowing which is based on the principles of System of Rice Intensification (SRI) is a new wheat cultivation technique that needs to maintain the plant to plant distance at $20 \mathrm{~cm}$ and $20 \mathrm{~cm}$ between lines. SWI ensures the proper plant density by providing sufficient aeration, moisture, sunlight, and nutrient availability to enhance the proper root system development from the initial stage of crop growth. System of Wheat Intensification (SWI) is one of the capable technologies which enhances the productivity eventually contributes to the household level food security of small and marginal farmers. Apart from sowing methods, another vital aspect to be considered is nutrient management.

The constant pulling out of nutrients from soils coupled with scarce and imbalanced fertilizer use has led to the emergence of multi-nutrient deficiency of at least seven nutrients $(\mathrm{N}, \mathrm{P}, \mathrm{K}, \mathrm{S}, \mathrm{Zn}, \mathrm{Fe}$, and $\mathrm{B})$ is most common in soils of U.P. While annual depletion of 36 million tonnes of nutrients (NPK) from the soil, has been assessed. However, the renewal through fertilizer is only 28 million tonnes, with a net annual scarcity of 8 million tonnes which keeps accumulating year after year depleting the soil fertility. The outcomes of many experiments evidently stated that even soil test based NPK application couldn't maintain crop yields at a higher level consistently (Ananda and Patil, 2005). The 'Customized Fertilizer' made up of a combination of Nitrogen (N), Phosphorus (P), Potassium (K), Sulphur (S), and Zinc ( $\mathrm{Zn})$ has been confirmed for hiking of wheat yield. They are exceptional and ready to use granulated fertilizers, formulated on scientific principles of plant nutrition by integrated with soil information, wide-ranging laboratory studies, and assessed through field research (Rakshit et al., 2012). The customized fertilizers were included in the Fertilizer Control Order (FCO) 1985, by the Central Fertilizer Committee as a new-fangled sort of fertilizers that are area, soil, and crop-specific have shown good potential to upheld soil health by warranting appropriate fertilization. These fertilizers simplify the application of the comprehensive assortment of plant nutrients in the accurate quantity and to getup, the specific requirement of a crop at different stages of growth, and are more pertinent under site-specific nutrient management practices. A wide range of customized fertilizer grades was proposed by companies was included in fertilizer control order which are multi-nutrient carriers intended to comprise primary, secondary, and micronutrients.

\section{Materials and Methods}

A field experiment was conducted during rabi season of 2019, at Crop research farm of Department of Agronomy at Sam Higginbottom University of Agriculture, Technology, and Sciences, Prayagraj which is located at $25^{\circ} 24^{\prime} 42^{\prime \prime} \mathrm{N}$ latitude, $81^{\circ} 50^{\prime} 56^{\prime \prime} \mathrm{E}$ longitude and $98 \mathrm{~m}$ altitude above the mean sea level (MSL). To assess the influence of Customized Fertilizer and Different Methods of Sowing on Wheat (Triticum aestivum L.). The experiment was laid out in Randomized Block Design comprising of 9 treatments 
which are replicated thrice. Each treatment net plot size is $3 \mathrm{~m} \times 3 \mathrm{~m}$. The treatment combination has two factors. First factor comprises of three methods of sowing i.e., Line sowing $(20 \times 10 \mathrm{~cm})$, Broadcasting, System of wheat intensification (SWI)(20x20 $\mathrm{cm})$ while second factor has state recommended dose of fertilizer(SRDF) (120: 60: 60)and two levels of Customized Fertilizer (CF) $100 \%$ and $75 \%$.

The treatment combinations are as follow $\left(\mathrm{T}_{1}\right)$ Line sowing + SRDF $(100 \%), \quad\left(\mathrm{T}_{2}\right)$ Broadcasting +SRDF (100\%), $\left(\mathrm{T}_{3}\right) \mathrm{SWI}+$ SRDF (100\%), $\left(\mathrm{T}_{4}\right)$ Line sowing $+100 \%$ RDF through $\mathrm{CF},\left(\mathrm{T}_{5}\right)$ Broad casting $+100 \%$ RDF through $\mathrm{CF}$, $\left(\mathrm{T}_{6}\right) \mathrm{SWI}+100 \% \mathrm{RDF}$ through C.F, $\left(\mathrm{T}_{7}\right)$ Line sowing $+75 \% \mathrm{RDF}$ through $\mathrm{CF},\left(\mathrm{T}_{8}\right)$ Broadcasting $+75 \% \mathrm{RDF}$ through $\mathrm{CF},\left(\mathrm{T}_{9}\right) \mathrm{SWI}+75 \% \mathrm{RDF}$ through CF. Customized Fertilizer applied as basal dose to fulfil the $\mathrm{N}$ requirement at early growth stages and rest of $\mathrm{N}$ requirement is fulfilled through urea as top dressing at 30 and 50 DAS. The variety selected was Halna (K-7903). Crop was harvested treatment wise at harvesting maturity stage. After harvesting, grains were separated from each net plot and were dried under sun for three days. Later threshing was done by using thresher and weight of grains per net plot value to per hectare was calculated and expressed in tonnes per hectare. Straw yield from each net plot was recorded after complete drying under sun and was expressed in tonnes per hectare.

The data was computed and analysed by statistical method given by Gomez and Gomez (1984). After thorough field preparation initial soil samples were taken to analyse for available major nutrients. Nitrogen $(\mathrm{N})$, phosphorous $(\mathrm{P})$, potassium (K), sulphur (S), Organic Carbon (OC), $\mathrm{pH}$ and soluble salts. The type of soil in experimental field is sandy clay. The $\mathrm{pH}$ of the experimental field was 7.3, EC of 0.47
$\mathrm{dSm}^{-1}$, organic carbon was $0.46 \%$. The $\mathrm{N}$ status of the experimental field was $(278 \mathrm{~kg}$ $\left.\mathrm{ha}^{-1}\right)$, available $\mathrm{P}\left(19.3 \mathrm{~kg} \mathrm{ha}{ }^{-1}\right)$ while available $\mathrm{K}$ status was in higher range $\left(238.3 \mathrm{~kg} \mathrm{ha}^{-1}\right)$. Growth parameters viz. plant height $(\mathrm{cm})$, No. of tillers plant ${ }^{-1}$, dry matter accumulation (g plant ${ }^{-1}$ ) were recorded manually on five randomly selected representative plants from each plot of each replication separately as well as yield and yield attributing character viz. grain yield $(\mathrm{t}$ $\mathrm{ha}^{-1}$ ), straw yield $\left(\mathrm{t} \mathrm{ha}{ }^{-1}\right.$ ), recorded as per the standard method. The oxidizable organic carbon was determined by Walkley and Black (1934), $\mathrm{pH}$ by $\mathrm{pH}$ meter and EC by electrical conductivity bridge with glass electrode in a 1:2.5 soil water suspension (Jackson 1973). Soil texture by the Bouyoucos Hydrometer Method (Gee and Baudev, 1986). Available nitrogen was determined by Subbiah and Asija (1956), Available phosphorus was determined by Olsen et al., (1954) and available potash was determined by Flame photometric method, Jackson (1973).

\section{Results and Discussion}

\section{Effect on growth parameters}

It is observed from Table.1, the plant height increased with crop growth duration. At 20DAS $\mathrm{T}_{7}$ recorded maximum plant height of $(4.01 \mathrm{~cm})$, whereas $\mathrm{T}_{6}$ recorded maximum plant height in rest of the growth stages i.e., at 40, 60, 80, and 100 DAS of 15.42, 42.26, 89.45 , and $87.96 \mathrm{~cm}$ respectively. At $80 \mathrm{DAS}$, $\left(\mathrm{T}_{9}\right) \mathrm{SW}$ I+ $75 \% \mathrm{RDF}$ through $\mathrm{CF}$ and at 100 DAS $\left(\mathrm{T}_{3}\right) \mathrm{SWI}+\mathrm{SRDF}(100 \%),\left(\mathrm{T}_{4}\right)$ Line sowing $+100 \%$ RDF through $\mathrm{CF},\left(\mathrm{T}_{7}\right)$ Line sowing $+75 \%$ RDF through $\mathrm{CF}$ and $\left(\mathrm{T}_{9}\right) \mathrm{SWI}+$ $75 \% \mathrm{RDF}$ through $\mathrm{CF}$ was found statistically at par to $\left(\mathrm{T}_{6}\right) \mathrm{SWI}+100 \% \mathrm{RDF}$ through $\mathrm{CF}$. The broadcasting method resulted in shortest plants compared to those recorded in SWI and line sowing treatments. 
Table.1 Effect of customized fertilizer and methods of sowing on plant height of wheat

\begin{tabular}{|c|l|c|c|c|c|c|}
\hline \multicolumn{2}{|c|}{ Treatments } & \multicolumn{5}{c|}{ Plant height(cm) } \\
\cline { 3 - 7 } & & 20 DAS & 40 DAS & 60 DAS & 80 DAS & At harvest \\
\hline $\mathbf{1}$ & Line sowing + SRDF (100\%) & 3.43 & 13.27 & 38.84 & 80.37 & 79.64 \\
\hline $\mathbf{2}$ & Broadcasting + SRDF (100\%) & 3.33 & 11.89 & 37.61 & 75.35 & 74.87 \\
\hline $\mathbf{3}$ & SWI + SRDF (100\%) & 2.83 & 13.40 & 39.89 & 82.09 & 81.33 \\
\hline $\mathbf{4}$ & Line sowing + 100\% RDF through CF. & 3.77 & 12.57 & 39.25 & 84.99 & 84.66 \\
\hline $\mathbf{5}$ & Broadcasting + 100\% RDF through CF. & 3.77 & 12.43 & 39.99 & 79.59 & 78.79 \\
\hline $\mathbf{6}$ & SWI + 100\% RDF through CF. & 3.43 & 15.42 & 42.26 & 89.45 & 87.96 \\
\hline $\mathbf{7}$ & Line sowing + 75\% RDF through CF. & 4.01 & 12.70 & 37.80 & 83.17 & 82.86 \\
\hline $\mathbf{8}$ & Broadcasting + 75\% RDF through CF. & 3.80 & 11.63 & 38.92 & 77.92 & 77.32 \\
\hline $\mathbf{9}$ & SWI + 75\% RDF through CF. & 3.43 & 13.97 & 40.73 & 86.34 & 85.32 \\
\hline & SEm( \pm ) & 0.26 & 0.42 & 1.36 & 2.66 & 2.34 \\
\hline & C.D (P=0.05) & NS & $* 1.26$ & NS & $* 4.08$ & $* 7.02$ \\
\hline
\end{tabular}

SRDF- State Recommended Dose of Fertilizer, CF-Customized Fertilizer, *Significant at $\mathrm{P}<0.05$; NS- Non significant at $\mathrm{P}>0.05$

Table.2 Effect of customized fertilizer and methods of sowing on No. of tillers of wheat

\begin{tabular}{|c|l|c|c|c|c|}
\hline \multirow{2}{*}{ Treatment } & \multicolumn{4}{|c|}{ No. of tillers plant } \\
\hline $\mathbf{1}$ & $\mathbf{4 0}$ DAS & 60 DAS & $\mathbf{8 0 ~ D A S}$ & At harvest \\
\hline $\mathbf{1}$ & Line sowing + SRDF (100\%) & 3.8 & 5.9 & 8.3 & 7.8 \\
\hline $\mathbf{2}$ & Broadcasting + SRDF (100\%) & 3.5 & 4.3 & 6.8 & 6.2 \\
\hline $\mathbf{3}$ & SWI + SRDF (100\%) & 3.5 & 6.9 & 9.1 & 8.5 \\
\hline $\mathbf{4}$ & Line sowing + 100\% RDF through CF. & 4.0 & 6.1 & 8.5 & 7.9 \\
\hline $\mathbf{5}$ & Broadcasting + 100\% RDF through CF. & 3.7 & 4.7 & 7.7 & 7.0 \\
\hline $\mathbf{6}$ & SWI + 100\% RDF through CF. & 4.9 & 8.1 & 12.2 & 11.9 \\
\hline $\mathbf{7}$ & Line sowing + 75\% RDF through CF. & 3.6 & 5.9 & 7.9 & 7.6 \\
\hline $\mathbf{8}$ & Broadcasting + 75\% RDF through CF. & 3.4 & 4.1 & 6.9 & 6.6 \\
\hline $\mathbf{9}$ & SWI + 75\% RDF through CF. & 4.0 & 7.4 & 11.4 & 11.1 \\
\hline & SEm ( \pm ) & 0.24 & 0.26 & 0.27 & 0.25 \\
\hline & C.D (P=0.05) & $* 0.71$ & $* 0.80$ & $* 0.82$ & $* 0.82$ \\
\hline
\end{tabular}

SRDF- State Recommended Dose of Fertilizer, CF-Customized Fertilizer, *Significant at $\mathrm{P}<0.05$ 
Table.3 Effect of Customized Fertilizer and methods of sowing on dry weight of wheat

\begin{tabular}{|c|l|c|c|c|c|c|}
\hline \multirow{2}{*}{ S.No. } & \multicolumn{5}{|c|}{ Treatments } & \multicolumn{4}{c|}{ Dry weight (gm) } \\
\cline { 3 - 7 } & & 20 DAS & 40 DAS & 60 DAS & 80 DAS & 100 DAS \\
\hline $\mathbf{1}$ & Line sowing + SRDF (100\%) & 0.19 & 1.84 & 7.27 & 13.44 & 20.79 \\
\hline $\mathbf{2}$ & Broadcasting + SRDF (100\%) & 0.18 & 1.32 & 6.16 & 10.05 & 15.00 \\
\hline $\mathbf{3}$ & SWI + SRDF (100\%) & 0.18 & 2.08 & 7.51 & 16.99 & 20.56 \\
\hline $\mathbf{4}$ & Line sowing + 100\% RDF through CF. & 0.17 & 2.25 & 7.69 & 14.56 & 20.48 \\
\hline $\mathbf{5}$ & Broadcasting + 100\% RDF through CF. & 0.18 & 1.66 & 6.56 & 12.57 & 17.50 \\
\hline $\mathbf{6}$ & SWI + 100\% RDF through CF. & 0.20 & 2.96 & 8.86 & 20.41 & 26.99 \\
\hline $\mathbf{7}$ & Line sowing + 75\% RDF through CF. & 0.20 & 1.64 & 7.17 & 14.41 & 19.13 \\
\hline $\mathbf{8}$ & Broadcasting + 75\% RDF through CF. & 0.21 & 1.62 & 6.23 & 11.16 & 16.59 \\
\hline $\mathbf{9}$ & SWI + 75\% RDF through CF. & 0.19 & 2.20 & 7.92 & 18.87 & 23.74 \\
\hline & SEm ( \pm ) & 0.02 & 0.17 & 0.18 & 0.91 & 0.98 \\
\hline
\end{tabular}

SRDF- State Recommended Dose of Fertilizer, CF-Customized Fertilizer, *Significant at $\mathrm{P}<0.05$; NS- Non significant at $\mathrm{P}>0.05$

Table.4 Effect of customized fertilizer and methods of sowing on grain yield, straw yield, harvest index in wheat

\begin{tabular}{|c|c|c|c|c|}
\hline S.No. & Treatments & $\begin{array}{c}\text { Grain yield } \\
\text { (t/ha) }\end{array}$ & $\begin{array}{c}\text { Straw } \\
\text { yield(t/ha) }\end{array}$ & Harvest index (\%) \\
\hline 1 & Line sowing + SRDF (100\%) & 3.0 & 4.11 & 42.19 \\
\hline 2 & Broadcasting + SRDF (100\%) & 1.8 & 3.04 & 36.04 \\
\hline 3 & SWI + SRDF (100\%) & 2.4 & 3.45 & 41.50 \\
\hline 4 & Line sowing $+100 \%$ RDF through CF. & 3.5 & 4.52 & 44.85 \\
\hline 5 & Broadcasting $+100 \%$ RDF through CF. & 2.1 & 3.01 & 37.75 \\
\hline 6 & SWI + 100\% RDF through CF. & 3.2 & 4.47 & 42.18 \\
\hline 7 & Line sowing $+75 \%$ RDF through $\mathrm{CF}$. & 3.1 & 3.96 & 42.94 \\
\hline 8 & Broadcasting $+75 \%$ RDF through CF. & 1.9 & 2.82 & 41.18 \\
\hline \multirow[t]{3}{*}{9} & SWI + 75\% RDF through CF. & 2.7 & 3.60 & 43.87 \\
\hline & $\operatorname{SEm}( \pm)$ & 0.24 & 0.15 & 1.54 \\
\hline & $\mathrm{CD}(\mathrm{P}=0.05)$ & $* 0.71$ & $* 0.46$ & $* 4.62$ \\
\hline
\end{tabular}

SRDF- State Recommended Dose of Fertilizer, CF-Customized Fertilizer, *Significant at $\mathrm{P}<0.05$ 
Table.5 Effect of Customized Fertilizer and methods of sowing on Economics of wheat

\begin{tabular}{|c|c|c|c|c|c|}
\hline \multicolumn{2}{|r|}{ Treatments } & \multirow{2}{*}{$\begin{array}{c}\begin{array}{c}\text { Cost of } \\
\text { cultivation } \\
\text { (Rs. ha }^{-1} \text { ) }\end{array} \\
28410\end{array}$} & \multirow{2}{*}{ 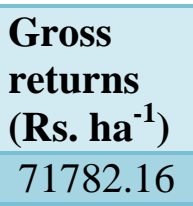 } & \multirow{2}{*}{ 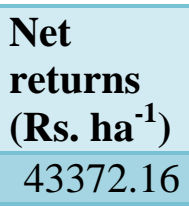 } & \multirow{2}{*}{ 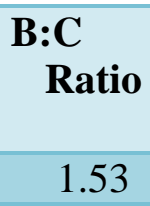 } \\
\hline 1 & Line sowing + SRDF (100\%) & & & & \\
\hline 2 & Broadcasting + SRDF (100\%) & 28585 & 44362.87 & 15777.87 & 0.55 \\
\hline 3 & SWI + SRDF $(100 \%)$ & 26660 & 57795.66 & 31135.66 & 1.17 \\
\hline 4 & Line sowing + 100\% RDF through CF. & 28482 & 82291.89 & 53809.89 & 1.89 \\
\hline 5 & Broadcasting $+100 \%$ RDF through CF. & 28657 & 49451.23 & 20794.23 & 0.73 \\
\hline 6 & SWI + 100\% RDF through CF. & 26732 & 75772.15 & 49040.15 & 1.83 \\
\hline 7 & Line sowing $+75 \%$ RDF through CF. & 27174 & 72313.19 & 45139.19 & 1.66 \\
\hline 8 & Broadcasting $+75 \%$ RDF through CF. & 27349 & 46360 & 19011 & 0.70 \\
\hline 9 & SWI + 75\% RDF through CF. & 25424 & 63040.74 & 37616.74 & 1.48 \\
\hline
\end{tabular}

SRDF- State Recommended Dose of Fertilizer, CF-Customized Fertilizer

Sowing with proper plant density facilitates for sufficient aeration, moisture, sunlight and nutrient availability, leading to proper root system development from the early stage of crop growth (Abraham et al., 2014) which enhanced the plant height. At all growth intervals i.e., 40, 60, 80, and at harvest $\left(\mathrm{T}_{6}\right)$ SWI $+100 \%$ RDF through $\mathrm{CF}$ recorded maximum no. of tillers per plant of $4.9,8.1$, 12.2 and 11.9 respectively, However, $\left(\mathrm{T}_{9}\right) \mathrm{SWI}+75 \% \mathrm{RDF}$ through $\mathrm{CF}$ was found statistically at par to $\left(\mathrm{T}_{6}\right) \mathrm{SWI}+$ $100 \%$ RDF through $\mathrm{CF}$ at 60, 80, and at harvest. Number of tillers was influenced significantly by different spacings and plating methods. SWI technique decreases the competition between the plants for light, water, space and nutrient hence there is increase number of tillers. There is increase in number of tillers in wheat crop due to influence of different fertilizer combinations (Singh et al., 2011). The higher number of tillers associated with soil test-based recommendation and customized fertilizers. At later stages of growth, the number of tillers might have increased due to enhanced cell expansion and various metabolic processes in the presence of abundant supply of nutrients (Laghari et al., 2010). At $20 \mathrm{DAS} \mathrm{T}_{8}$ recorded maximum dry matter accumulation of
$0.21 \mathrm{gm}$, whereas $\left(\mathrm{T}_{6}\right) \mathrm{SWI}+100 \% \mathrm{RDF}$ through $\mathrm{CF}$ recorded maximum dry weight in the rest of growth intervals i.e., 40, 60, 80, and 100 DAS of $2.96 \mathrm{~g}, 8.86 \mathrm{~g}, 20.41 \mathrm{~g}$, and $26.99 \mathrm{~g}$ respectively. At $80 \mathrm{DAS},\left(\mathrm{T}_{9}\right) \mathrm{SWI}+75$ $\%$ RDF Through CF was found statistically at par to maximum. The cause of rapid increase of Dry matter accumulation at crop harvest or ripening stage was possibly due to emergence of number of new tillers plant ${ }^{-1}$ and more fertile spikes plant ${ }^{-1}$ (Alam, 2013).

\section{Yield}

Data pertaining to grain yield are recorded after harvest and embodied in Table: 4. Grain yield significantly increased with treatment combinations. The maximum yield was recorded with $\left(\mathrm{T}_{4}\right)$ Line sowing $+100 \% \mathrm{RDF}$ through $\mathrm{CF}$, due to high plant population producing more grain yield $(8.5 \%)$ than treatment Line sowing + SRDF (100\%) (3.5t/ha) and also $\left(\mathrm{T}_{6}\right) \mathrm{SWI}+100 \% \mathrm{RDF}$ through $\mathrm{CF}$ (3.2t/ha). The similar results are found by Kumar et al., (2015).The significantly maximum stover yield $(1.1 \%)$ also found under maximum grain yield producing treatment $\left(\mathrm{T}_{4}\right)$ viz. Line sowing + $100 \%$ RDF through $\mathrm{CF}(4.52 \mathrm{t} / \mathrm{ha})$ which is followed by treatment $\left(\mathrm{T}_{6}\right) \mathrm{SWI}+100 \% \mathrm{RDF}$ 
through CF (4.47t/ha). The minimum stover yield recorded with treatment $\left(\mathrm{T}_{2}\right)$ Broadcasting + SRDF (100\%) (3.04t/ha). The positive impact of availability of individual plant nutrients and humic substances from balanced supplement of NPKS and $\mathrm{Zn}$ through inorganic fertilizers might have induced cell division, expansion of cell wall, meristematic activity, photosynthetic efficiency and regulation of water intake into the cells, resulting in the enhancement of yield parameters (Singh et al., 2008).Significantly maximum harvest index found with treatment $\left(\mathrm{T}_{4}\right)$ Line sowing + $100 \%$ RDF through CF which produce maximum grain and stover yield also.

\section{Economics}

It is revealed from the data presented in Table 5 . The cost of cultivation of wheat varied from Rs. 25,424 to Rs. $28,657 \mathrm{ha}^{-1}$ owing to the use of different methods of sowing and different levels of customized fertilizer and state recommended treatment. Among all the treatments, highest net return Rs. 53,809 ha ${ }^{-1}$ was observed in treatment $\left(\mathrm{T}_{4}\right)$ Line sowing + $100 \%$ RDF through C F. The highest amount of gross returns also found in treatment $\mathrm{T}_{4}$ Line sowing $+100 \%$ RDF through C F with returns of Rs.82,291 ha ${ }^{-1}$. The same trend was observed in $\mathrm{B}: \mathrm{C}$ ratio. The $\mathrm{B}: \mathrm{C}$ ratio was observed highest under treatment $\left(\mathrm{T}_{4}\right)$ Line sowing $+100 \%$ RDF through CF (1.89) treatment and lowest under control treatment $\left(\mathrm{T}_{2}\right)$ Broadcasting + SRDF (100\%) (0.55).

In conclusion the experiment with treatment Methods of sowing and different levels of Customized Fertilizer on Wheat, treatment T6 (SWI $+100 \%$ RDF Through C F) was found to be desirable for plant height, number of tillers, plant dry weight, crop growth rate, effective tillers, length of spike, No of grains, test weight. While treatment T4 (Line sowing $+100 \%$ RDF through $\mathrm{CF}$ ) recorded the maximum grain yield, Net returns and Benefit Cost ratio.

\section{Acknowledgements}

I express my gratitude to my advisor Prof. (Dr.) Joy Dawson for constant support, guidance and for his valuable suggestions for improving the quality of this work. I am indebted to Prof. (Dr.)Thomas Abraham who has been a constant source of inspiration and all the faculty members of Department of Agronomy, SHUATS, Prayagraj, Uttar Pradesh (U.P), India for providing necessary facilities, for their cooperation, encouragement and support.

\section{References}

Abraham, B., Araya, H., Berhe, T., Edwards, S., Gujja, B., Khadkas, R. M., Koma, Y. S., Sen, D., Sharif, A., Styger, E., Uphoff, N and Verma, A. 2014. The system of crop intensification: reports from the field on improving agricultural production, food security, and resilience to climate change for multiple crops. Agriculture and food security, 3:4.

Adhikari, D. (2013). System of wheat intensification in farmers field of Sindhuli, Nepal Agronomy Journal of Nepal (Agron JN) 3.

Alam, M. S., 2012. Effect of sowing patterns and nitrogen rates on quality traits and yield of wheat. Journal of Environmental Science and Natural Resources.5(1): 267- 272.

Ananda, N., and Patil, B. N. 2005. Effect of Micronutrients ( $\mathrm{Zn}$ and $\mathrm{Fe}$ ) and Time of Nitrogen Application on Growth and Yield of Durum Wheat. Karnataka J. Agric. Sci. 18(3): 604-608.

Anonymous, APEDA2019. Analytical trade profile of Basmati rice. APEDA Agriexchange. In: https://agriexchange.apeda.gov.in/index 
p/reportlist.aspx

Bhargava, C., Deshmukh G., Sawarkar S. D., Alawa S. L. and Ahirwar, J. (2016). The system of wheat intensification in comparison with convention method of wheat line sowing to increase wheat yield with low input cost. Plant Archives 16 (2):801-804.

Chopra, R., Sharma, M., Sharma, S.K., Nepalia, V., Jain, H.K. and Singh, A. 2016. Effect of integrated nutrient management on growth and yield of wheat (Triticum aestivum L.) in haplustipts. 7(3): 622-628.

Dwivedi, S. K. and Meshram, M. R. (2014). Effect of Customized fertilizer on productivity and nutrient uptake of rice (Oryza sativa). Indian Journal of Agronomy. V: 59, 2: 247-250.

Dwivedi, S. K., Meshram, M. R. and N. Pandey, (2014). Response of customized fertilizer on wheat (Triticum aestivum) under Chhattisgarh condition. The Bioscan, 9(4): 15091512.

Gee, G.W. and Baudev, J.W. 1986. Particle size analysis. Inmethods of soil analysis. Part 1, Physical and mineralogical method (A. Kluse Ed) pp. 404-408. Agronomy monogram No. 9, American Society of Agronomy, Madisom, w1.

Jackson, M.L. 1973. Soil Chemical Analysis. Prentice Hall of India Pvt. Ltd., New Delhi. pp. 56.

Jan, M. T., Ali, H., and Jan, A. (2001). Influence of sowing method and mulching on yield and yield component of wheat. Pakistan journal of biological science 4(6): 657-659.

Jayawardena, S. N. and Abeysekera, S.W. (2011) Effect of plant spacing on the yield of hybrid rice, Rice Research and Development Institute, Batalagoda, Ibbagamuwa.

Kalaiselvi, B. 2016. Effect of TNAU
Customozed Fertilizer on Sustaining soil fertility and enhancing the maize yield. Madras Agricultural Joural. 103, 10-12:320-326.

Kaleeswari, R. K. 2013. Impact of Customized Fertilizer on Yield and soil properties of lowland Rice Ecosystem. Madrs Agric. J., 100 (1-3): 150-152.

Khan, A., Arif, M., Shah. A., Ali, S., Hussain Z. and Khan, S. 2007. Evaluation of planting methods for grain yield and yield components of wheat. Sarhad J. Agric. Vol. 23, No. 3.

Kumar, A., Rishi, R., Shiva, D. and Pandey, U.C. 2015. Performance of System of Wheat Intensification (SWI) and conventional wheat sowing under North Eastern Plain Zone of India. Ann. Agric. Res. New SeriesVol. 36(3): 258-262.

Laghari GM, Oad FC, Tunio S, Gandahi AW, Siddiqui $\mathrm{MH}$, Jagirani AW, et al., Growth, yield and nutrient uptake of various wheat cultivers under different fertilizer regimes. Sarhad J Agric.2010; 26(4):489-497.

Mudalagiriyappa., Raghavendra, G.B., Ramachandrappa, B. K. and Nanjappa, H.V. 2015. Influence of customized fertilizers on growth and yield of finger millet (Eleusine coracana (L.) Gaertn.) in alfisols of southern India. Inian Journal of Dryland agricultural Research and Development 30, 1: 5054.

Rakshit, R., Rakshit, A. and Das, A., Customized fertilizers: marker in fertilizer revolution. Int. J. Agril. Environ. Biotech., 2012, 5(1), 67-75.

Singh, C. M., P., Mishra, P. K., Singh, A. P., Verma, R., Raha, P., 2011. Impact of integrated nutrient management on growth, yield and nutrient uptake by wheat (Triticum aestivum L.). Asian J. Agricultural Research. 5(1):76-82.

Singh, C. M., Sharma, P. K., Kishor, P., 
Mishra, P. K., Singh, A. P., Verma, R., Raha, P., 2015. Impact of integrated nutrient management on growth, yield and nutrient uptake by wheat (Triticum aestivum L.). Asian J. Agricultural Research. 5(1):76-82.

Singh, R. and Agrawal, S. K. (2005). Effect of levels of farm yard manure and nitrogen fertilizer on grain yield and use efficiency of nutrients on wheat (Triticum aestivum). Indian $J$. Agricultural Science 75(7): 408-413.

Singh, R., Singh, B. and Patidar, M. 2008. Effect of preceding crops and nutrient management on productivity of wheat (Triticum aestivum L.) based cropping system in arid region. Indian Journal of Agronomy, 53 (4):267-272.

Tiwari, D. K., Singh, G. R., Singh, S. P. and Pandey, S. K. (2016) Performance of wheat (Triticum aestivum L.) under different customized fertilizers and moisture regime in eastern Uttar Pradesh. Environment and ecology, 34(3): 947-952.

Walkley A and Black I A, 1934. An examination of degtjareff method for determining soil organic matter and a proposed modification of chromic acid titration method. Soil Sci 37: 29-37.

\section{How to cite this article:}

Chereddy Maheshwara, Chakravarthy Thejesh and Joy Dawson. 2020. Influence of Customized Fertilizer and Different Methods of Sowing on Wheat (Triticum aestivum L.). Int.J.Curr.Microbiol.App.Sci. 9(10): 3828-3836. doi: https://doi.org/10.20546/ijcmas.2020.910.440 